Prewar Domestic Conditions and Civilians in War

(forthcoming at Journal of Global Security Studies)

H. Zeynep Bulutgil

Department of Political Science

University College London

z.bulutgil@ucl.ac.uk 
Ana Arjona. 2016. Rebelocracy: Social Order in the Colombian Civil War. New York: Cambridge University Press, 263 pp.

Laia Balcells. 2016. Rivalry and Revenge: The Politics of Violence during Civil War. New York: Cambridge University Press, 263 pp.

Evgeny Finkel. 2017. Ordinary Jews, Choice and Survival during the Holocaust. Princeton, NJ: Princeton University Press, 279 pp.

Abbey Steele. 2017. Democracy and Displacement in Colombia's Civil War. Ithaca, NY: Cornell University Press, 243 pp.

Scott Straus. 2015. Making and Unmaking Nations: War, Leadership, and Genocide in Modern Africa. Ithaca, NY: Cornell University Press, 386 pp.

\section{Prewar Domestic Conditions and Civilians in War}

What explains the variation in civilian victimization during international or civil wars?

What are the conditions under which the civilians themselves resist or avoid becoming targets of violence? And when is it possible for the noncombatants to negotiate the terms of their participation in civil wars or military occupations?

These questions are fundamental for the study of civilians in war, a research agenda that focuses on civilian victimization as well as civilian strategies for survival and resistance during wars. ${ }^{1}$ Thus far, the theoretical arguments in this field have been dominated by two approaches. The first approach emphasizes the impact of military balance of power on the state and non-state actors' willingness to engage in violence against civilians. These arguments suggest that the military balance of power, the severity and duration of territorial competition, and expectations about these factors determine the extent of violence against noncombatants (Pape 1996; Arreguin-Toft 2001; Valentino et. al. 2004; Kalyvas 2006; Downes 2008, Wood 2010). While differing on their specifics, these arguments share the

\footnotetext{
${ }^{1}$ For the origins of the conceptual difference between violence within wars and causes of wars, see Kalyvas (2006). For examples of other early studies that focus on violence within wars, see Pape (1996); ArreguinToft (2001); Weinstein (2007); Valentino et. al. (2004); Downes (2008); Wood (2010); Kocher et. al. (2011).
} 
idea that military forces use violence against civilians to deprive their rivals of supporters and prevail in war.

The second dominant approach focuses on the resources available to the militant groups. The studies in this category contend that when military organizations do not rely on the civilians for recruitment and material resources, they engage in higher levels of violence against them (Weinstein 2007; Humphreys and Weinstein 2006; Salehyan et. al. 2014; Toft and Zhukov 2015; Zhukov 2017). The relevant studies propose two non-mutually exclusive causal mechanisms. First, the military organizations that rely on outside aid or easily exploitable natural resources neglect internal discipline and fail to protect the civilians. Second, organizations with easy access to loot attract the type of individuals who are motivated by short-term material rather than long-term ideological reasons and hence are less inclined to follow military discipline.

The five books that are under review make significant contributions to the study of civilians in war by diverging from these approaches in two respects. ${ }^{2}$ First, they start from the observation that even when controlling for the balance of military power or material resources, one still observes substantial variation in the violence against civilians as well as in how the civilians react to such violence. Second, all the books suggest causal mechanisms that link specific aspects of prewar domestic conditions (e.g. organizational capabilities of civilian leaders, political party loyalty, state and leadership ideology) to patterns of violence

\footnotetext{
${ }^{2}$ For earlier studies that focus on genocide and highlight prewar factors, see Fein (1979); Rummel (1995); Goldhagen (1996); Naimark (2001); Kaufman (2001); Mann (2005); Eck and Hultman (2007). These studies focus on macro conditions such as modernization, history of interethnic relations, and regime-type. The reviewed books push this literature forward by specifying how macro historical and institutional factors shape the treatment of civilians in wars.
} 
and resistance during wars. (Table 1 summarizes the argument and corresponding prewar domestic conditions for each book.)

Table 1: The Arguments and Corresponding Prewar Domestic Conditions

\begin{tabular}{llll}
\hline $\begin{array}{l}\text { Reviewed } \\
\text { Book }\end{array}$ & Dependent Variables & Independent Variables & Prewar Domestic Conditions \\
\hline $\begin{array}{l}\text { Arjona } \\
(\mathbf{2 0 1 6 )}\end{array}$ & $\begin{array}{l}\text { Civilian resistance to } \\
\text { rebel rule }\end{array}$ & Local institutions & Organizational capabilities of civilian leaders \\
\hline $\begin{array}{l}\text { Balcells } \\
(\mathbf{2 0 1 7})\end{array}$ & $\begin{array}{l}\text { Indirect/direct violence } \\
\text { against civilians }\end{array}$ & Electoral results & Party loyalties of civilians \\
\hline $\begin{array}{l}\text { Finkel } \\
\mathbf{( 2 0 1 7 )}\end{array}$ & $\begin{array}{l}\text { Civilian reactions to } \\
\text { extreme repression or } \\
\text { violence }\end{array}$ & $\begin{array}{l}\text { Type of repression } \\
\text { National assimilation }\end{array}$ & $\begin{array}{l}\text { Organizational capabilities of civilian leaders } \\
\text { State and Leadership Ideology }\end{array}$ \\
\hline $\begin{array}{l}\text { Steele } \\
(\mathbf{2 0 1 7})\end{array}$ & $\begin{array}{l}\text { Displacement of } \\
\text { civilians }\end{array}$ & Electoral results & Party loyalties of civilians \\
\hline $\begin{array}{l}\text { Straus } \\
(\mathbf{2 0 1 5})\end{array}$ & Genocide & Founding narratives & State and Leadership Ideology \\
\hline
\end{tabular}

In Making and Unmaking Nations, Scott Straus asks why, when faced with security threats, certain state leaders decide to use genocide while others do not. Straus, whose earlier work showed how the security-related considerations of leaders affect patterns of violence, fully recognizes the relevance of military threats for genocide (Straus 2006). His point in this book, however, is that among the Sub-Saharan African states in which there was substantial military threat from a rebel organization, many still did not escalate their policies to the level of genocide. To study this variation, Straus uses comparative historical analysis of five African states: Rwanda, Cote D'Ivoire; Mali, Sudan, and Senegal. His analysis identifies a variety of micro, meso, and macro-level conditions that serve as constraints on the possibility of genocide. But the main explanatory factor in the book is the type of "founding narrative" (multiethnic and inclusive versus monoethnic and exclusive) that emerges during critical periods in the history of each country (Straus 2015, 58).

Laia Balcells' Rivalry and Revenge studies two types of violence during civil wars: direct violence, which includes face-to-face violence often perpetrated with light weaponry; 
and indirect violence, which involves distant methods of victimization such as bombing. Using data from the Spanish Civil War, Balcells observes that the territories that were far away from the frontlines and hence under an uncontested military zone nevertheless display substantial variation in violence (Balcells 2017, 14, 76-86). The analysis then shows that the results from the 1936 Spanish elections exerted a significant influence on both direct and indirect violence. The municipalities in which the 1936 elections were more competitive experienced higher levels of direct violence, which Balcells attributes to higher levels of civilian denunciations in these contexts. Indirect violence was most common in areas of large electoral support for the other side. ${ }^{3}$

Abbey Steele's Democracy and Displacement studies another outcome: displacement during civil wars. Theoretically, she also agrees with the notion that territorial contestation is an important determinant of displacement (Steele 2017, 37). Like the other books, she also goes beyond this notion. Her argument is that when there are institutional connections between the macro-party cleavage that defines the civil war and micro-level units such as urban neighborhoods and villages, the combatants use this information to identify and displace the disloyal individuals (Steele 2017, 39-45). First time elections with small districts provide precisely this type of information to the fighting parties. Steele supports her theory with individual level data from the municipality of Apartado in Colombia and with municipal level data across Colombia. Additionally, the qualitative analysis in the book provides a rich description of the causal process that connects elections to displacement in Colombia (Steele 2017, 126-138).

\footnotetext{
${ }^{3}$ Balcells shows that as the war progressed, dynamics internal to the war such as revenge exerted a larger impact on direct violence (Balcells 2017, 122-123).
} 
Evgeny Finkel's Ordinary Jews focuses on potential responses to extreme violence and repression. The book studies why the Jewish populations in Nazi controlled ghettos articulated different responses that ranged from cooperation, coping, evasion, to resistance. Empirically, while Finkel conducts a systematic analysis of the ghettos (Finkel 2017, 214221), the main findings emanate from the comparison of three middle sized ones: Minsk, Bialystok, and Krakow. His main conclusions, drawing from survivors' testimonies, leaders' memoirs, and official documents are threefold. First, the type of prewar political repression (selective or indiscriminate) shaped the skill set of Jewish leaders and determined whether they could organize resistance (Finkel 2017, 161-163). Second, the prewar socialintegration of Jewish populations determined whether they could survive if they escaped from the ghetto (Finkel 2017, 101; 127-130). Third, prewar isolation from the non-Jewish population, while decreasing the chances of survival outside the ghetto, enabled the Jewish communities to cope with the conditions inside the ghetto in an organized manner (Finkel 2017, 101).

Finally, in Rebelocracy, Ana Arjona studies the types of order that emerge during irregular civil wars. The first part of the book distinguishes between zones of disorder, in which there is no social contract between the combatants and civilians; and zones of order, in which a social contract exists. Based on surveys, interviews, and memory workshops, Arjona constructs indicators for order, distribution of control, military discipline, and reliance on natural resources in seventy-four Colombian communities (Arjona 2016, 122131). Her findings agree with the existing literature. Territorial competition, organizational indiscipline, and natural resources make zones of order unlikely. The second part of the book identifies two types of social-contract within the zones of order: rebelocracy (in which the militants get deeply involved in civilian affairs) and aliocracy (in which the militants 
only focus on gathering information and taxation) (Arjona 2017, 3). Arjona uses crosscommunity data and comparison of three communities to show that prewar local institutions are the main causes of this divergence.

The rest of the article proceeds in three steps. First, I provide a summary and critique of the "military balance" or "material resources" arguments. Second, based on the reviewed works, I identify three prewar factors that shape the treatment and behavior of civilians in war: i. Organizational Capabilities of Civilian Leaders. ii. Political Party Loyalties of Civilians iii. State and Leadership Ideology. ${ }^{4}$ Finally, the conclusion discusses implications for future research and policy.

\section{Military Balance, Material Resources, and Civilians in War: What is missing?}

The literature that emphasizes military balance of power can be divided into studies that focus on irregular wars, in which clear frontlines are missing and at least one side relies on light military technology; and studies that focus on conventional wars with clear frontlines and heavy weaponry. ${ }^{5}$

According to these arguments, the main problem for the insurgents and state forces fighting irregular wars is the identification of individuals who aid the other side by providing food, shelter, and information. Given this basis, the existing literature provides two insights. First, the level of violence within irregular wars depends on the willingness of civilians to denounce each other, which in turn depends on the distribution of control on the

\footnotetext{
${ }^{4}$ For new studies on civilian victimization that focus on international factors, see Jo and Simmons (2016); Stanton (2016); Fazal (2018), Wood and Molfino (2016). In this article, I explicitly focus on domestic conditions.

${ }^{5}$ Both irregular and conventional wars might include civil and international wars. On conventional and nonconventional civil wars, see Kalyvas and Balcells 2010.
} 
ground (Kalyvas 2006). When one side firmly controls territory or there is balance between the two sides, victimization is rare either because the combatants do not need denunciations or because the civilians do not provide them out of fear of retaliation. Hence, the highest levels of selective violence occur in areas of asymmetrical but mixed control. Second, the studies that focus on military balance also argue that when the combatants cannot collect individual level information via denunciations, they resort to collective victimization of populations in regions generally considered to be supporting the other side (Valentino et. al. 2004).

The arguments that focus on conventional wars follow a similar logic but, because the relationship between the civilians and military organizations is different, the logic makes different predictions. The states (or non-state actors) that are involved in these types of wars still rely on civilians for material resources and recruitment, but these resources are collected via the routinized mechanisms of tax collection and conscription that precede the war rather than ad-hoc policies adopted after the conflict starts. Moreover, due to the existence of clear frontlines, the identification of disloyal individuals is not as central an issue in conventional wars. Thus, in these types of conflicts, the fighting parties target civilians for two reasons: a. to win the war quickly by demoralizing the adversary and destroying its war-related infrastructure; b. to eliminate the collective groups deemed to be irretrievably loyal to the other side (Pape 1996; Arreguin-Toft 2001; Downes 2008).

In contrast to the theories that follow the logic of military balance, the studies that focus on material resources follow the logic of military discipline in irregular wars (Weinstein 2007; Humphreys and Weinstein 2006; Salehyan et. al. 2014; Toft and Zhukov 2015; Zhukov 2017). They argue that when militant organizations have access to easily extractable natural resources or foreign aid, they tend to engage in higher levels of civilian 
victimization for two reasons. First, when these sources are not available, the militant groups rely on the noncombatants and therefore avoid victimizing them. Second, when easily accessible resources are available, the individuals who are motived by short-term goals of self-aggrandizement rather than long-term ideological goals join the insurgency. The result is an organization composed of individuals who are difficult to discipline, even if the initial leadership would have preferred to curtail civilian victimization (Weinstein 2007).

The contributions of both approaches to our understanding of the treatment and behavior of civilians in wars are invaluable. Yet, there are also empirical and theoretical grounds for thinking that they provide a very incomplete picture of what goes on during wars. Evidence from existing work shows that when controlling for factors that relate to military conditions and/or economic resources during wars, we still observe remarkable variation in the patterns of violence and civilian responses. As discussed, the five books under review all provide such empirical examples. Other works that analyze a diverse set of cases, ranging from Eastern European Empires during World War I to the insurgent-state relationship in South Asian conflicts, also show that similar military and economic conditions do not necessarily result in similar intra-war behavior (Staniland 2012; Suny 2015, 231-232; Bulutgil 2017).

There are also theoretical reasons to question the dominance of military and resource-based explanations. These explanations themselves often bring in prewar factors into their explanations but leave this portion of the argument undertheorized. For example, when discussing the logic of denunciation in irregular wars, Kalyvas (2006, 178-180) suggests that prewar local conflicts between neighbors, spouses, and friends can play a role during the war. The main theory in the work, however, explicitly focuses on distribution of 
control and does not incorporate these prewar micro-divisions. Yet not only are prewar local cleavages and institutions potentially relevant to the topic, historical evidence shows that, as states modernize, national level political cleavages and organizations often come to shape the local level (Weber 1982; Weber 1976). In most countries there are mechanisms and institutions such as elections, political parties, trade unions, and religious organizations that translate and connect the national level to the local one (Weber 1982; Wittenberg 2006). Hence, prewar macro cleavages and institutions are potentially as relevant for the study of civilians in war as the local ones.

The arguments that focus on military balance in conventional wars also implicitly bring in features of the prewar setup. For example, the idea that the victimization of civilians behind the enemy lines demoralizes the combatants presumes that the combatants consider themselves to be part of the same national community as the civilians being targeted. This assumption would not hold in wars in which the primary combatants are mercenaries or members of a military class that is ideologically detached from the rest of the population. ${ }^{6}$ Likewise, the idea that some types of social groups are (or are perceived to be) irretrievably loyal to the other side presumes the existence of compelling national ideologies that depict certain groups as belonging to the state while excluding others. The broader point here is that states vary in their ability to disseminate a convincing ideology as well as in the type of ideology they disseminate. Given the underlying logic of the military balance arguments,

\footnotetext{
${ }^{6}$ For examples of studies that connect national identity formation to effectiveness of war making, see Tilly (1990); Wimmer (2012); Darden and Mylonas (2015).
} 
both the prewar effectiveness of dissemination and the nature of the ideology should influence the states' treatment of civilians. ${ }^{7}$

The studies that focus on material resources also incorporate prewar factors into their explanations. For example, studying participation in the civil war in Sierra Leone, Humphreys and Weinstein (2006) identify prewar local networks (measured as prewar interpersonal connections and ethnic homogeneity) as factors that enhance discipline and limit civilian victimization. Their findings also raise additional issues. First, interpersonal connections from before the war might account for why individual militants coordinate on the same policy. But they do not necessarily explain why the particular policy the militants converge on corresponds to avoiding civilian victimization as opposed to coordinated and organized violence against them. After all, killing, looting, and rape do not always result from lack of discipline among combatants. Instead, strategic leaders following a certain set of rules often organize these acts (Wood 2009; Straus 2006). Hence, the analysis of civilian victimization needs to go beyond the logic of military discipline and ask what kinds of prewar institutions or ideological beliefs result in coordination on high versus low levels of civilian victimization. Second, if networks from before the war influence the behavior of combatants, it is also possible that they influence the ability of the civilians to escape or counter violence by the combatants. Not only are these civilian reactions worthy of scholarly attention but they might also influence the strategic calculus of the combatants and their use of violence. ${ }^{8}$

\footnotetext{
${ }^{7}$ Some existing studies already link certain types of identity differences to civilian victimization in wars (Fazal 2015).

${ }^{8}$ On this point, also see Kalyvas (2007).
} 


\section{Organizational Capabilities of Civilian Leaders and Civilians in War}

Among the reviewed books, Finkel's provides the most explicit theory of how organizational skills that civilian leaders develop prior to war shape their ability to resist violent actors during war. He argues that to set up resilient resistance organizations, the Jewish leaders in the ghettos needed both operational capacity and security (Finkel 2017, 162). These leaders had to establish the organization so that its members would be able to convene meetings, identify informers, and gather weapons and intelligence, while avoiding detection. The crux of Finkel's argument is that establishing this type of tight underground organization required prior experience which itself was a function of the prewar political institutions. In contexts where the leaders faced selective repression before the war, they already knew how to establish clandestine organizations. In contexts where the prewar regime was either not repressive or used indiscriminate repression, the aspiring resistance leaders had not acquired these skills and hence the Germans eliminated them easily.

Finkel tests this argument by studying the Communist and Zionist resistance movements in three ghettos: Minsk (under Soviet rule until German occupation), Krakow (under Polish rule until German occupation), Bialystok (under Polish rule in the interwar period, Soviet occupation in 1939-1941, and German occupation in 1941-1945). Finkel suggests that the prewar Polish state selectively repressed leftwing groups and hence the communist Jews in Bialystok and Krakow had the opportunity to learn how to organize resistance. The Zionist organizations in Bialystok also had exposure to selective repression during Soviet rule that lasted between 1939 and 1941. In contrast, the Zionists in Krakow and Jewish organizations in Minsk did not experience selective repression and thus their leaders did not acquire the skills to run a successful clandestine organization. 
Finkel's analysis shows that the communist resistance in Krakow was more successful than its Zionist counterpart and in Bialystok both the communists and the Zionists established organizations that survived for a significant period. Surprisingly, in Minsk Finkel also finds resilient resistance. Through detailed analysis of the Minsk movement, he shows that the leadership of the resistance in Minsk actually arrived from Poland. Until the Polish Jews with the necessary skills arrived in this ghetto, the attempts to resist German rule failed due to the amateurish mistakes of the leaders.

The argument and the empirical evidence presented by Finkel are both impressive. Nevertheless, the theory needs further specification on the antecedent prewar conditions that result in skilled organizers. It is not clear why selective repression should result in the skill set to establish clandestine organizations but indiscriminate repression should not. The argument in the book goes as follows. When individuals are involved in organizations that repressive regimes target selectively, they have the choice between opting out and continuing (Finkel 2017, 163). The members of the small group who choose to continue face a high likelihood of getting caught and hence are incentivized to learn the necessary operational skills (Finkel 2017, 163). By contrast, under conditions of indiscriminate repression, the probability of becoming a target is distributed evenly across the population and hence "first movers face an increasing not decreasing risk of punishment (Finkel 2017, 163)." These circumstances only change if there is imminent lethal threat but by then individuals do not have the time to acquire the necessary skills.

This argument leaves unresolved issues. To begin, following Finkel's Olsonian logic, no individual should endeavor to organize resistance against regimes that use selective repression in the first place. The reason is that, at least until they learn to evade state surveillance, the first movers would also be significantly increasing, rather than 
decreasing, their risk of punishment. The fact that communist organizations emerged in interwar Poland and, more generally, clandestine organizations do emerge in repressive regimes indicates that risk-taking individuals who are willing to make the first move exist. If this is the case, it is not clear why such individuals would not also establish organizations aimed at resisting regimes that use indiscriminate repression.

To continue, as Finkel himself recognizes, the assumption that first movers face an increasing risk of punishment does not always hold (Kalyvas and Kocher 2011). Under conditions of very high-level repression, forming and joining clandestine resistance might actually be better than not forming or joining. The fact that even the Jewish populations in Nazi ghettos organized resistance is a testament to this theoretical point. Arguably, the Soviet Union under Stalin, which killed and incarcerated millions of people (Snyder 2010), would count as a regime of high level indiscriminate repression rather than a low level one and hence should, and sometimes did, result in resistance (Rossman 2002, 72; McDonald 2002). Thus, the finding that the Soviet Jews were not as well or better adapted to organizing resistance against the Nazis than their Polish counterparts remains intriguing despite Finkel's argument.

It goes beyond the goals of this article to propose a fully developed alternative. However, it is useful to highlight how prewar domestic factors other than selective repression might explain why the Soviet Jews did not have sufficient experience with running clandestine organizations. For example, it is possible that the state apparatus of the Soviet Union was simply better equipped than its Polish counterpart for monitoring and catching resistance groups. Hence, the incipient resistance organizations in this context never survived long enough to provide training for their leaders. Put otherwise, it might 
have been the effectiveness, rather than selectiveness of repression, that made the difference.

Finkel's argument also opens a new line of inquiry about whether sustained and indiscriminate prewar repression can result in organizations aimed at activities other than resistance. The book studies not only resistance but also the whole gamut of Jewish responses in the ghettos including "evasion," which involves adopting a fake identity or fleeing. While Finkel does not extend his argument about prewar institutions and leadership skills to the study of evasion, it is in principle possible to do so. Experience with sustained indiscriminate repression in the prewar period might incentivize individuals to form organizations aimed at evasion rather than resistance. These organizations would help individuals hide, relocate within the country, or flee to other countries. But they would not acquire weapons, conduct military operations, and directly target the state. In wartime, the leaders of these organizations would be more adept at aiding escape than directly harming the occupying forces. Understanding the relationship between prewar institutions and wartime organization of evasion would be theoretically interesting both for its own sake and because organized evasion constitutes a potential alternative to organized resistance.

Ana Arjona also provides a theory of how prewar local leadership and organization influences civilian collective action against combatants during civil wars. Her main argument is that high quality local level leadership and organization make it easier for communities to live under "aliocracy," in which they pay taxes to the insurgents but sustain control over matters such as conflict resolution and marriage. When communities do not enjoy high quality prewar institutions and leaders, they give in to "rebelocracy" and the insurgent group imposes rules that go beyond taxation that reshape the social, political, and economic life. According to Arjona, high quality local organizations exhibit effectiveness 
(locals widely observe the rules of the community) and legitimacy (locals consider the rules of the community just) (Arjona 2016, 67). Aliocracy emerges only if both these characteristics exist because only in these contexts do the communities possess both the willingness to resist and the ability to organize collectively.

Arjona supports her arguments in a variety of ways. She uses statistical analysis based on detailed information on the type of social order and prewar local institutions. She also demonstrates the causal mechanisms behind the argument by comparing three villages (Zama, Tellus, Librea), which shared a history of leftwing agrarian activism but diverged institutionally when the leaders of the movement settled in Zama. Arjona makes three observations: first, the leadership in Zama remained more active before the civil war; second, during the war FARC rebels tried to influence Zama by first contacting the leaders, whereas in Tellus and Librea they met with several actors and forged several alliances, and third, despite repeated attempts by FARC, the leadership in Zama sustained aliocracy.

Arjona's study is remarkable for its conceptual innovation and empirical richness. However, the analysis also ignores other prewar domestic factors that could shape wartime order. Following the military-security based logic, Arjona assumes that rebel organizations always prefer rebelocracy to aliocracy; therefore, local civilian institutions are the main determinants of wartime order (Arjona 2016, 55, 56). Yet other studies give us reason to think that this assumption might not always hold and prewar conditions might shape whether insurgent groups prefer rebelocracy or not.

For example, Paul Staniland finds that compatibility between the ideology and goals of states and militant organizations influences whether states seek to establish full control over these groups (Staniland 2015; Staniland 2012). Similarly, it is possible that rebel groups have different preferences depending on whether the local leaders share their 
ideological goals. This possibility is particularly relevant because according to Arjona legitimacy is a critical component of the relationship between the local leaders and civilian population. Yet the theory ignores the potential role of legitimacy when it comes to the relationship between the local leaders and rebel organization. If considerations about just rule influence civilian-local leader relations, then they could also shape the relations between the local leaders and rebel organization. ${ }^{9}$ When the notions of justice in the community and rebel organization are compatible with each other, then the rules of conduct that govern political, social, and economic life under rebelocracy and aliocracy might be indistinguishable from each other. Under such conditions, rebel organizations might willingly allow aliocracy or a smooth transition to rebelocracy might spontaneously emerge. ${ }^{10}$

Daniel Ziblatt's study of state formation in Germany and Italy highlights another potential prewar factor (Ziblatt 2006). Ziblatt asks why the Prussian leaders ended up adopting a federal system, whereas the Piedmontese leaders adopted a unitary system that involved significant intervention from the center. He suggests that, even though leaders in both contexts initially favored a federal system, in Italy the weakness of the local institutions forced the center to intervene to perform fundamental functions. In Germany, by contrast, the Prussian leadership could rely on the efficient subnational institutions that were already in place. In this argument, local organizational capability plays a role not because it allows for collective action against the center but because it allows the center to have a reliable

\footnotetext{
${ }^{9}$ Preexisting social networks between rebels and civilians might also make it easier for insurgent groups to organize (Zukerman Daly 2016; Parkinson 2013).

10 Arjona's analysis does suggest that ideological affinity between local organizations and FARC made aliocracy easier but the theory does not posit an explicit role for this factor (Arjona 2016, 165).
} 
counterpart at the local level. The extension of this logic to rebel controlled territories is obvious. Aliocracy need not emerge due to successful communal resistance to unrelenting insurgent pressure. It might emerge because when effective local institutions exist, rebel organizations can delegate certain governing functions to the local leaders and divert their resources elsewhere.

\section{Political Party Loyalty and Civilians in War}

Both Balcells' and Steele's books articulate theories that link party loyalties, revealed through elections, to violence against civilians during wars. Balcells studies two types of violence: indirect violence, which includes impersonal violence conducted through bombing; and direct violence involving face-to-face violence during civil wars. She argues that in both types of violence, recent elections from before the war play a significant role, though the causal stories are different. For direct violence, the driving mechanism is local level electoral competition. Where electoral competition is intense, the local leaders have an incentive to denounce the leaders of the opposition as doing so shifts the fragile political balance to their advantage and ensures future electoral success (Balcells 2017, 32, 33). Municipal level analysis of Catalonia, Aragon, and Malaga in the early stages of the war shows that, while controlling for distance to frontlines, direct violence was more prevalent in municipalities in which the 1936 elections were closer to parity.

For indirect violence, Balcells follows the existing literature that emphasizes shortterm security-related factors. She argues that indirect violence was a means to eliminate the supporters of the other side and increase the chances of winning the war. In her argument, electoral results from before the war provide the necessary information for militants to identify clusters of their rivals' supporters. She backs this argument by showing that the 
extent of prewar support for leftwing parties had a positive impact on aerial bombing in Catalonia by the Nationalists during the war.

Balcells' book outlines an original theory of denunciation and uses rigorous empirical analysis. However, the study also leaves the question of how prewar elections shape denunciations and violence partially unresolved. Balcells posits that local leaders use denunciations to shift the future balance of electoral competition to their advantage. As she acknowledges, for this logic to hold, the local leaders need to expect that the postwar arrangement will be a democracy with meaningful electoral competition (Balcells 2017, 33n29). Yet it is not immediately clear why there would have been a general expectation for postwar democracy in Spain, her primary case. ${ }^{11}$ Spanish history up to that point did not necessarily warrant such an expectation. From 1881 to 1923 , the leaders of the two main parties manipulated elections to alternate in government and then from 1923 to 1930, Spain was a dictatorship under Primo Rivera (Carr 1966, 356-357; Callahan 2012, 26). Only in the short period between 1932 and 1936 did the Spanish elections become free and competitive enough to qualify as a democratic system (Payne 1993). Furthermore, by believing in a postwar democracy, the Nationalists would be betting against their own side, which did not advocate a democratic system.

Given these issues, I suggest considering two potential adjustments to Balcells' argument. Both these adjustments incorporate other prewar conditions. First, it is possible that Balcells' forward-looking electoral logic only applies when other prewar factors are also in place. Some historians have argued that Spanish electoral competition at the municipal level was already robust in larger urban centers such as Barcelona, Madrid and

\footnotetext{
${ }^{11}$ Balcells' secondary case, Cote D'Ivoire, also did not have a tradition of democratic rule.
} 
some provincial capitals in the early $20^{\text {th }}$ century (Payne 1993, 30). Given their prior experience, the individuals in these particular contexts might have expected a postwar democratic system and behaved according to Balcells' electoral logic. One way to test this argument would be to evaluate whether the findings of the book depend on the extent to which a certain locality was already urban and electorally competitive in the early $20^{\text {th }}$ century. $^{12}$

Second, Balcells' forward-looking electoral logic might not be the one that links electoral competition to direct violence. Instead, prewar electoral rivalry might generate polarization, which might then motivate denunciations and cause direct violence in wartime. Balcells' analysis uses an index of polarization based on the 1933 elections and finds this variable to be insignificant (Balcells 2017, 128). However, this finding does not negate the possibility that political polarization generated by the 1936 elections could have been the main cause of denunciations and direct violence. Balcells prefers to use the 1933 elections to construct the polarization index because the 1936 elections involved competition between two large fronts instead of separate parties (Balcells 2017, 128n50). By her account, due to the existence of the two competing blocks, the indicators for polarization and competition for the 1936 elections would have been the same (Balcells 2017, 128n50). Ultimately, the only way to adjudicate between the polarization logic and the future-looking electoral logic is to conduct more in-depth qualitative studies of motivations behind denunciations in regions with competitive elections.

\footnotetext{
${ }^{12}$ Balcells reports that urbanization positively correlates with violence but, rightfully, suggests that this is probably due to higher population density in urban contexts. The models do not interact urbanization and electoral competition.
} 
Steele's book focuses on forced displacement during the civil war in Colombia. She also starts from the idea that identification of disloyal individuals is of paramount importance during irregular civil wars. Like Balcells, she pushes the existing theories forward by arguing that elections provide a potential tool for the fighting sides to identify the disloyal individuals. She argues that elections based on small districts are particularly revealing because they connect the national level macro-cleavage to the local level and allow the militant groups to identify ideological opponents (Steele 2017, 5). Steele relies on in-depth analysis of the Colombian civil war to develop this argument. Her motivating puzzle is that even though the civil war in Colombia started in late 1960s, forced displacement of civilians did not become a prevalent feature of the conflict until after 1986 (Steele 2017, 120). Her argument is that the reason for the appearance of displacement in this period is the introduction of competitive elections at the local level after the peace accord of 1984, in which the FARC affiliated political party, Union Patriotica (UP), participated. After these elections, the paramilitary forces could rely on the election results in small communities to identify and target the potential FARC supporters for political cleansing.

Steele's analysis diverges from Balcells in that it relies equally on qualitative and quantitative analysis based on the municipality of Apartado and Colombia in general. ${ }^{13} \mathrm{Her}$ findings show that the paramilitary groups were more likely to target those communities in which UP received more support. But they also demonstrate that, at least in Apartado, this pattern applied to urban but not rural communities. In further qualitative analysis, Steele argues that the rural communities in Apartado often possessed better coping mechanisms,

\footnotetext{
${ }^{13}$ For other works that link elections to violence in civil wars, see Belge 2016; Birnir and Gohdes 2018.
} 
including leadership and ability to organize peace communities, which allowed them to withstand paramilitary pressure to leave (Steele 2017, 171-172).

The most visible argument in Democracy and Displacement is the parsimonious one that links elections to the identification and displacement of disloyal individuals. However, upon careful reading, the book also offers a more nuanced and convincing causal story. Steele not only assembles and evaluates quantitative evidence but she also describes how exactly elections ultimately restarted the war and led to widespread displacement. This part of the analysis, which relies on some 200 interviews, identifies a four-step process (Steele 2017, 131-137). First, the elections in late 1980s allowed UP to replace the long-established Liberal local leaders in some communities. Second, these Liberal leaders were resentful about losing power and hence turned to the paramilitaries to target UP. Third, the paramilitaries began to target UP leaders, which then refueled the war with FARC. Finally, once the civil war reignited, the paramilitaries started to use the election results to eliminate not only the UP leaders but also all suspected UP-FARC supporters.

This nuanced causal story, more than the stylized and parsimonious version of the argument, is Steele's major contribution to the study of civilians in wars. To begin with, this version of the argument is theoretically different from the former one. The argument in this case highlights the role of elections as generating resentment, polarization, and invitation for militants as opposed to merely providing identifying information to preexisting militants. In some respects, this theoretical story is closer to the one suggested in Balcells' book for direct violence but, unlike Balcells' study, Steele emphasizes 
polarization due to past elections rather than calculations about future electoral competition. $^{14}$

To continue, the nuanced version of the argument can account for two empirical puzzles that stand out in Steele's analysis. First, even though the initial elections were held in 1986, according to Steele's own data, the number of forcefully displaced did not pick up until late 1990s (Steele 2017, 138). This lag period could be explained with the detailed causal story that Steele presents according to which elections first generated Liberal backlash, rekindled the war, and only then resulted in displacement. Second, the nuanced causal story might also account for the urban-rural difference that Steele identifies in Apartado. For example, it is possible that rural communities were less likely to have resentful Liberal leadership and more likely to have autonomous politically nonaligned leadership. If so, they might have been less vulnerable to paramilitary attack and more likely to display organized resistance (resembling Arjona's "aliocracy") when faced with paramilitary violence.

\section{Ideology and Civilians in War}

Prewar conditions can also influence the treatment of civilians in wars by shaping the ideological lens through which the leaders and ordinary citizens understand the world. Among the books reviewed, Straus' is the one that most explicitly provides a theory of why leaders might use different ideological lenses when they assess comparable situations and how these differences relate to the treatment of civilians during war.

Straus argues that if the leaders have been exposed to a "founding narrative" that is multiethnic, inclusive, and egalitarian in its treatment of different ethnic groups, then they

\footnotetext{
${ }^{14}$ Steele explicitly states that the motivation for violence was not winning future elections (Steele 2017, 199)
} 
imagine alternatives to genocide even when faced with security threats (Straus 2015, 5758). By contrast, if the leaders' experience includes a monoethnic, exclusive, and nonegalitarian narrative, they converge on genocide relatively quickly without imagining alternatives. ${ }^{15}$ The "founding narratives" themselves emerge during periods of critical juncture and are a result of systematic factors such as the socio-economic history of the country as well as random factors such as the leaders who are in charge during periods of transition (Straus 2015, 63).

Straus relies on a comparison of five countries in Sub-Saharan Africa that have all experienced security challenges related to civil wars but reacted to these challenges differently. In Sudan and Rwanda, where an exclusive and monoethnic narrative prevailed, the leaders chose the path of genocide. In Cote D'Ivoire, Mali, and Senegal, where an inclusive and multiethnic founding narrative was dominant, the leaders followed alternative courses of action such as selective violence targeting the suspected supporters of the rebels. The comparative analysis of Cote D'Ivoire, where the first president developed an inclusive founding narrative, and Rwanda, where the exclusive ideology of Hutu power emerged, illustrates the argument particularly well.

Straus' book offers an original argument and convincing comparative analysis of genocide in Africa. It also faces two questions that relate to prewar ideology. First, as Straus acknowledges, within the leadership of the same country, one often finds multiple competing ideologies that relate to ethnicity (Straus 2015, 65; 185-189). Furthermore, the balance of political power among leaders with different approaches to ethnicity often varies overtime (Bulutgil 2016). Thus, a critical challenge for theories of ethnic cleansing and

\footnotetext{
${ }^{15}$ For a somewhat similar argument, see Kaufman (2001).
} 
genocide is to specify the conditions under which the leaders with intolerant ideologies overcome or assimilate the leaders with tolerant ones.

Second, the theory also raises questions on the identification and timing of the founding period in which the dominant ideology emerges. Straus argues that in Sub-Saharan Africa, the immediate periods that follow decolonization or end of one-party rule constitute founding periods (Straus 2015, 63). This specification, however, leaves conceptual ambiguities that have implications for generalizability, testability, and causal sequence. Without a prior theory of what constitutes a founding period, it is not clear how this framework would apply to regions such as Europe, where countries have typically been through several critical junctures. Moreover, Straus' discussion on Mali shows that the dominant narratives in African states also change and sometimes this change occurs right before or during civil wars (Straus 2015, 171, 172). If the dominant ideological narrative can change right before or during the civil war then it is possible that leaders with genocidal inclinations (or leaders with opposing tendencies) come to power for reasons that are exogenous to the founding narrative and then they transform the narrative to fit their goals.

The issues highlighted above emerge especially when Straus discusses the nonAfrican cases in the book: a. Germany and the Holocaust, b. Ottoman Empire and the Armenian Genocide. For Germany, Straus argues that the founding narrative of the Third Reich, Nazism, made the German leaders prone to implementing a full-scale extermination policy once the war started. It is indisputable that the ideology of Nazism was the main proximate cause of the Holocaust. What is open to dispute, however, is Straus' decision to set the founding narrative in Germany to the beginning of the Third Reich. After all, before the Third Reich, there was the Weimar Republic with a democratic, inclusive constitution and a collection of political parties that did not emphasize racial and ethnic issues. Among 
these parties, the Social Democratic Party, in which German Jews held leadership positions, was electorally the largest until the 1932 elections (Kerwin 1932; Evans 2003). Even in the 1933 elections, the combined electoral strength of the Social Democrats and the Communists was more than balanced against the National Socialist Party (NSDAP) (Evans 2003, 294). What led to Nazi dominance was not the prevalence of a racist founding narrative in the Weimar Republic but the inability of the Social Democrats and Communists to put aside their ideological differences and unite against the NSDAP (Evans 2003). Once in power, the Nazis successfully forged a new narrative by eliminating the German political leaders and organizations with the potential to disagree with their ideology (Snyder 2010, $63,64)$.

Similar issues also emerge in the analysis of the Ottoman Empire. Up to $19^{\text {th }}$ century, the Ottoman state relied on the "millet" system that was multiethnic, inclusive, and tolerant in that each of the main faith communities ran their own internal affairs. Straus rightfully observes that this system did not confer equal citizenship rights as the non-Muslim population paid certain taxes that the Muslims did not. However, not surprisingly for this historical period, neither the Muslims nor the Christians had citizenship rights in the modern sense (Inalcik 1997, 16, 17). In fact, for its time, the Ottoman practice of millet system was comparatively tolerant of difference (Barkey 2008).

This system began to change in the $19^{\text {th }}$ century. The first steps towards a modern state arrived with the Tanzimat Decrees in 1839, which introduced citizenship rights to Muslims, Christians, and Jews alike. At this point, the political trend was towards a more, not less, egalitarian multiethnic system. Over the course of late $19^{\text {th }}$ and early $20^{\text {th }}$ century, partially driven by territorial losses, part of the Ottoman elite became increasingly nationalist and exclusionary towards the Christian minorities. Even then, until 1913 there 
were political factions and parties with influential members that preferred a tolerant approach towards the Christian minorities (Ahmad 1982). Only after the loss of substantial territory during the First Balkan War did the radical nationalists successfully purge their more tolerant rivals.

In both the German and Ottoman cases, we observe a leadership ideologically divided in its approach to the minorities instead of a leadership that largely coalesces around a dominant exclusivist ideology. In both contexts, the radical nationalist or racist leaders rendered their intolerant monoethnic ideology dominant by taking over the political system and eliminating the rival leaders who offered a more tolerant ideology. Thus, the theories that link prewar ideology to wartime dynamics need to go beyond identifying the dominant ideological narrative and study why the relative strength of radical nationalist ideologies vis-à-vis tolerant alternatives varies across countries and periods. ${ }^{16}$

These cases also raise questions about the timing of the founding narrative. Is the relevant founding period in Germany the Third Reich, the Weimar Republic, or an earlier period? For the Ottoman Empire, is it appropriate to consider the millet system, the immediate post-Tanzimat period, or the post-1913 period? The answer matters as depending on the founding period, the dominant narrative and the prediction of the theory changes. Therefore, for the founding narrative framework to offer testable predictions, we need an ex-ante theory that identifies the founding periods and narratives without taking into account the ex-post minority policies of the state.

\footnotetext{
${ }^{16}$ For studies that theoretically tackle this question, see Petersen (2002); Midlarsky (2005); Mylonas (2013); Bulutgil (2016); Bulutgil (2017).
} 
Finkel also brings state ideology into his analysis by linking it to civilian evasion of genocidal policies. One of Finkel's important observations about Jewish evasion during the Holocaust is that the major obstacle that the would-be evaders faced was not escape from the ghetto but survival once they escaped (Finkel 2017, 127). The German occupiers were typically unable to distinguish between the local non-Jewish and Jewish individuals but the Polish and Ukrainian neighbors of the Jews were able to do so (Finkel 2017, 127). Hence, the survival of Jewish escapees often depended on non-Jewish individuals who would refrain from denouncing them and offer food, shelter and passage to safer areas.

Finkel argues that whether the Jews had access to this support depended on their connections with the non-Jewish populations before the war and their ability to pass as nonJewish. He suggests that these characteristics themselves were a function of states' education policies during the prewar period. Unlike the Russian Empire and interwar Poland, the Soviet Union and Austro-Hungarian Empire encouraged the assimilation of Jewish populations through public schools and employment. Thus, the Jews had sufficient knowledge of the non-Jewish culture and Slavic language around them to avoid identification. Furthermore, prior connections with the non-Jewish population through school and work also increased the chances that the Jews would find food, shelter, and accommodation once they escaped. These factors explain why the Jews in Minsk (formerSoviet territory) and Krakow (under Austro-Hungary until 1918) were more successful at evasion compared to those in Bialystok (formerly part of the Russian Empire and interwarPoland).

Finkel's analysis also alludes to other features of the prewar political system that contributed to successful evasion. One such feature is the existence of political parties in which both Jews and non-Jews were politically active. When discussing evasion in Krakow, 
Finkel briefly mentions that in this context the local members of the Polish Socialist Party organized a Polish Council to Aid Jews, an affiliate of the Polish Government-in-exile (Finkel 2017, 147). The role of this organization was to provide Jews with the necessary resources and documents to survive. Among the many examples of evasion that Finkel identifies, this one is exceptional as it was an organized effort aimed at saving Jews in general rather than an individual effort to save the Jews who were acquaintances. Future research should focus more on organized evasion during episodes of mass violence and the impact of prewar party ideology on this behavior.

\section{Conclusion: Future Research and Policy Implications}

Like other sophisticated and original works, the books under review leave several unresolved questions for future research. These questions fall into two categories: those that relate to the antecedents of the prewar domestic conditions that the new research identifies and those that relate to the micro-mechanisms that link the prewar domestic factors to the treatment and behavior of civilians in war.

On antecedents, this essay identified two important questions. The first is about the conditions under which civilian leaders develop organizational skills in the prewar period. The reviewed works and the discussion in this essay raise three possibilities. According to Finkel, selective repression (as opposed to no repression or indiscriminate repression) results in leaders with organizational skills. In contrast, Arjona's village level comparative analysis suggests that experienced leaders cluster into specific regions through historical coincidence and this geographical concentration generates a path dependent pattern of better local organization. Finally, in this essay, I suggested that it might be the effectiveness, rather than selectiveness, of the prewar repression that determines whether leaders with organizational skills survive until the prewar period. To adjudicate among these arguments, 
we need additional detailed studies that process-trace the institutional and historical steps that select out skilled leaders.

The second question on antecedents relates to how leaders with intolerant ethnic ideologies overcome leaders with tolerant approaches. As discussed, this issue is important as empirical research identifies significant ideological diversity among the leadership of multiethnic countries. Straus' argument posits that dominant ideological narratives that emerge during critical periods determine the relative strength of tolerant and intolerant leaders. A different argument is that non-ethnic social cleavages (such as class) within dominant ethnic groups influence the relative strength of tolerant leaders vis-à-vis intolerant ones (Bulutgil 2016; Bulutgil 2017). According to this argument, political leaders who prioritize issues other than ethnicity tend to have a more cooperative and inclusive approach toward ethnic minorities. When such leaders are organizationally strong in the prewar period, they also have a better chance of obstructing the leaders who want to use ethnic cleansing during wars (Bulutgil 2017). Future research that compares these two antecedent conditions should explore whether and how dominant ideological narratives and crosscutting (or reinforcing) cleavages influence each other.

On the micro-mechanisms that link prewar conditions to civilians in war, the unresolved issue is what motivates denunciations that result in violence. The reviewed works suggest several potential mechanisms. Balcells' study posits forward-looking actors who use denunciations to manipulate the profile of voters and win future elections. A critical implication of the argument is that the local denouncers have democratic expectations. Steele's study provides two potential mechanisms. First, electoral results in small communities provide militant groups the means to identify and eliminate disloyal individuals. In this mechanism, the agency of local actors and denunciations do not play a 
noteworthy role. According to the other mechanism that Steele outlines, elections themselves generate polarization and resentment among the electoral losers. The losers then use invitations and denunciations to combatant groups to eliminate the new comers they resent. Future research can compare these causal mechanisms by focusing on the motivations as well as future expectations of denouncers in electorally competitive contexts.

The reviewed works also highlight two types of factors with potential policy implications. The first includes structural factors such as long-term processes of state and nation building, social cleavages, and regime type. These factors are ordinarily not open to easy manipulation by domestic politicians or international actors and therefore do not provide practical tools for preventing civilian victimization during wars. However, they do offer relevant guidelines for postwar institution building. Unlike ordinary times, the periods that immediately follow wars and civil wars open a window of opportunity to establish new institutions and lock-in benign future patterns. The discussion here identified several desirable institutional characteristics: state education policies that encourage assimilation and routine interaction between groups, electoral systems that promote political parties with non-ethnic socio-political concerns, and persistent dissemination of ideologies that encourage an inclusionary narrative.

Finally, Balcells' and Steele's books offer practical advice for actors who would like to prevent civilian victimization in conflict zones. Regardless of the differences in their causal mechanisms, both works suggest that it is dangerous to conduct elections during ongoing civil wars as well as international wars that involve territorial contestation. The argument here is not that democratic elections are not desirable. On the contrary, repeated democratic elections could contribute to the emergence of the benign structural conditions mentioned above. In the short run, however, it would be better to postpone elections until 
after the war is completely over or there are sufficient numbers of international troops on the ground to prevent the war from restarting.

\section{References}

Ahmad, Feroz. 1982. "Unionist Relations with the Greek, Armenian, and Jewish Communities of the Ottoman Empire, 1908-1914." In Christians and Jews in the Ottoman Empire: The Functioning of a Plural Society, edited by Benjamin Braude and Bernard Lewis, 401-34. New York: Holmes and Meier.

Arreguin-Toft, Ivan. 2001. "How the Weak Win Wars: A Theory of Asymmetric Conflict." International Security 26 (1): 93-128.

Barkey, Karen. 2008. Empire of Difference. The Ottomans in Comparative Perspective. Cambridge: Cambridge University Press.

Belge, Ceren. 2016. "Civilian Victimization and the Politics of Information in the Kurdish Conflict in Turkey." World Politics 68 (2): 275-306.

Birnir, Johanna K. and Anita Gohdes. 2018. "Voting in the Shadow of Violence: Electoral Politics and Conflict in Peru.” Journal of Global Security Studies 3 (2): 181-197.

Bulutgil, Zeynep H. 2016. The Roots of Ethnic Cleansing in Europe. New York: Cambridge University Press.

Bulutgil, Zeynep H. 2017. "Ethnic Cleansing and its Alternatives in Wartime: A Comparison of the Austro-Hungarian, Ottoman, and Russian Empires." International Security 41 (4): 169-201.

Callahan, William J. 2012. The Catholic Church in Spain 1875-1998. Washington D.C.: Catholic University of America Press.

Carr, Raymond. 1966. Spain 1808-1939. London: Oxford University Press.

Cunningham, Kathleen G., Kristin Bakke, and Lee J.M. Seymour. 2012. "Shirts Today, Skins Tomorrow, Dual Contests and the Effects of Fragmentation in Self-Determination Disputes." Journal of Conflict Resolution 56 (11): 67-93.

Darden, Keith and Harris Mylonas. 2015. "Threats to Territorial Integrity, National Mass Schooling, and Linguistic Commonality." Comparative Political Studies 49 (11): 14461479.

Downes, Alexander B. 2008. Targeting Civilians in War. Ithaca, NY: Cornell University Press. 
Eck, Kristine and Lisa Hultman. 2007. "One-sided violence against civilians in war: Insights from new fatality data." Journal of Peace Research 44 (2): 233-246.

Fazal, Tanisha and Brooke Greene. 2015. "A Particular Difference: European Identity and Civilian Targeting.” British Journal of Political Science 45 (1): 829-851.

Fazal, Tanisha. 2018. Wars of Law: Unintended Consequences in the Regulation of Armed conflict. Ithaca, NY: Cornell University Press.

Fein, Helen. 1979. Accounting for Genocide: National Responses and Jewish Victimization during the Holocaust. Chicago, IL: University of Chicago Press.

Goldhagen, Daniel. 1996. Hitler's Willing Executioners: Ordinary Germans and the Holocaust. New York: Alfred A. Knopf.

Evans, Richard J. 2003. The Coming of the Third Reich. New York: Penguin.

Humphreys, Macartan and Jeremy M. Weinstein. 2006. "Handling and Manhandling Civilians in Civil War.” American Political Science Review 100 (3): 429-447.

Inalcik, Halil. 1997. Economic and Social History of the Ottoman Empire, Volume 1. Cambridge: Cambridge University Press.

Kalyvas, Stathis N. 2006. The Logic of Violence in Civil Wars. New York: Cambridge University Press.

Kalyvas, Stathis N. 2007. "Book Reviews: Weinstein, J. M. (2007). Inside Rebellion: The Politics of Insurgent Violence.” Comparative Political Studies 40 (9): 1146-1151.

Kalyvas, Stathis N. and Matthew Adam Kocher. 2007. "How "Free" is free-rising in Civil War? Violence, Insurgency, and Collective Action Problem.” World Politics 59 (2): 177216.

Kalyvas, Stathis N. and Laia Balcells. 2010. "International System and Technologies of Rebellion: How the end of Cold War Shaped Internal Conflict." American Political Science Review 104 (3): 415-429.

Kaufman, Stuart J. 2001. Modern Hatreds: The Symbolic Politics of Ethnic War. Ithaca, NY: Cornell University Press.

Kerwin, Jerome G. 1932. "The German Reichstag Elections of July 1932." American Political Science Review 26 (5): 921-926.

Kocher, Matthew Adam, Thomas B. Pepinsky, and Stathis Kalyvas. 2011. "Aerial Bombing and Counterinsurgency in the Vietnam War." American Journal of Political Science 5 (2): 211-218.

Mann, Michael. 2005. The Dark Side of Democracy: Explaining Ethnic Cleansing. New 
York: Cambridge University Press.

Midlarsky, Manus. 2005. The Killing Trap: Genocide in the Twentieth Century. New York: Cambridge University Press.

McDonald, Tracy. “A Peasant Rebellion in Stalin's Russia.” In Contending with Stalinism: Soviet Power and Popular Resistance in the 1930s, edited by Lynne Viola, 84109. Ithaca, NY: Cornell University Press.

Mylonas, Harris. 2013. The Politics of Nation-Building: The Making of Co-Nationals, Refugees, and Minorities. New York: Cambridge University Press.

Naimark, Norman. 2001. Fires of Hatred: Ethnic Cleansing in Twentieth-Century Europe. Cambridge, MA: Harvard University Press.

Pape, Robert A. 1996. Bombing to win: Air power and coercion in war. Ithaca, NY: Cornell University Press.

Parkinson, Sarah Elizabeth. 2013. "Organizing Rebellion: Rethinking High-Risk Mobilization and Social Networks in War" American Political Science Review 107 (3): 418-432.

Payne, Stanley. 1993. Spain's First Democracy 1931-1936. Madison, Wisconsin: University of Wisconsin Press.

Petersen, Roger. 2002. Understanding Ethnic Violence: Fear, Hatred and Resentment in Twentieth-Century Eastern Europe. Cambridge: Cambridge University Press.

Rossman, Jeffrey J. 2002. “A Workers strike in Stalin's Russia: The Vichuga Uprising in 1932." In Contending with Stalinism: Soviet Power and Popular Resistance in the 1930s, edited by Lynne Viola, 44-84. Ithaca, NY: Cornell University Press.

Rummel, R. J. 1995. "Democracy, Power, Genocide, and Mass Murder.” Journal of Conflict Resolution 39 (1): 3-26.

Salehyan, Idean, David S. Siroky and Reed Wood. 2014. "External Rebel Sponsorship and Civilian Abuse: A Principal Agent Analysis of Wartime Atrocities.” International Organization 68 (3): 633-661.

Snyder, Timothy. 2010. Bloodlands: Europe Between Hitler and Stalin. New York: Basic Books.

Staniland, Paul. 2012. "States, Insurgents and Wartime Orders." Perspectives on Politics 10 (2): 243-263.

Staniland, Paul. 2015. "Militias, Ideology, and the State" Journal of Conflict Resolution 59 (5): 770-793. 
Stanton, Jessica. 2016. Violence and Restraint in Civil War: Civilian Targeting in the Shadow of International Law. Cambridge University Press.

Straus, Scott A. 2006. The Order of Genocide: Race, Power, and War in Rwanda. Ithaca: Cornell University Press.

Suny, Ronald G. 2015 "They Can Live in the Desert but Nowhere Else”: A History of the Armenian Genocide. Princeton, N.J.: Princeton University Press.

Tilly, Charles. 1990. Coercion, Capital, and European States, AD 990-1990. Cambridge, MA: Blackwell.

Toft, Monica and Yuri M. Zhukov. 2015. "Islamists and Nationalists: Rebel Motivation and Counter Insurgency in Russia's South Caucasus." American Political Science Review 109 (2): 222-238.

Valentino, Benjamin, Paul Huth, and Dylan Balch-Lindsay. 2004. “'Draining the Sea': Mass Killing and Guerilla Warfare.” International Organization 58 (2): 375-407.

Weber, Eugen. 1982. "Comment la Politique Vint aux Paysans: A Second Look at Peasant Politicization." The American Historical Review 87 (2): 357-389.

Weber, Eugen. 1976. Peasants into Frenchmen: The Modernization of Rural France. Stanford: Stanford University Press.

Weinstein, Jeremy M. 2007. Inside Rebellion: The Politics of Insurgent Violence. New York: Cambridge University Press.

Wimmer, Andreas. 2012. Waves of War: Nationalism and Ethnic Politics in the Modern World. Cambridge: Cambridge University Press.

Wittenberg, Jason. 2006. Crucibles of Political Loyalty: Church Institutions and Electoral Continuity in Hungary. New York: Cambridge University Press.

Wood, Elisabeth Jean. 2009. "Armed Groups and Sexual Violence: When is Wartime Rape Rare?” Politic and Society 37(1): 131-161.

Wood, Reed. 2010. "Rebel Capability and Strategic Violence against Civilians." Journal of Peace Research 47(5): 601-14.

Wood, Reed and Emily Molfino. 2016. "Aiding Victims, Abetting Violence: The Influence of Humanitarian Aid on Violence Patterns During Civil Conflict." Journal of Global Security Studies 1(3): 186-203.

Zhukov, Yuri. 2017. "External Resources and Indiscriminate Violence: Evidence from German-occupied Belarus.” World Politics 61(1): 54-97. 
Ziblatt, Daniel. 2006. Structuring the State: The Formation of Italy and Germany and the Puzzle of Federalism. Princeton, NJ: Princeton University Press.

Zukerman Daly, Sarah. 2016. Organized Violence after Civil War: The Geography of Recruitment in Latin America. New York: Cambridge University Press. 